University of Nebraska - Lincoln

DigitalCommons@University of Nebraska - Lincoln

Agronomy \& Horticulture -- Faculty Publications

Agronomy and Horticulture Department

3-1992

\title{
Registration of N28 and N29 Sweetclover Germplasms
}

Herman J. Gorz

United States Department of Agriculture

Francis A. Haskins

University of Nebraska-Lincoln, fhaskins@neb.rr.com

G. R. Manglitz

United States Department of Agriculture

R. R. Smith

United States Department of Agriculture

K. P. Vogel

United States Department of Agriculture, kvogel1@unl.edu

Follow this and additional works at: https://digitalcommons.unl.edu/agronomyfacpub

Part of the Plant Sciences Commons

Gorz, Herman J.; Haskins, Francis A.; Manglitz, G. R.; Smith, R. R.; and Vogel, K. P., "Registration of N28 and N29 Sweetclover Germplasms" (1992). Agronomy \& Horticulture -- Faculty Publications. 242. https://digitalcommons.unl.edu/agronomyfacpub/242

This Article is brought to you for free and open access by the Agronomy and Horticulture Department at DigitalCommons@University of Nebraska - Lincoln. It has been accepted for inclusion in Agronomy \& Horticulture -Faculty Publications by an authorized administrator of DigitalCommons@University of Nebraska - Lincoln. 


\section{REGISTRATION OF N28 AND N29 SWEETCLOVER GERMPLASMS}

Two SWEETCLOVER [Melilotus officinalis (L.) Lam.] germplasms, N28 (Reg. no. GP-2, PI 552553) and N29 (Reg. no. GP-3, PI 552554), are improved biennial, yellow-flowered strains selected for low coumarin content (or, more accurately, for low content of $o$-hydroxycinnamic acid $\beta$ D-glucoside; [1]) and for resistance to the sweetclover aphid (Therioaphis riehmi Börner). N28 and N29 were developed cooperatively by the USDA/ARS and the Nebraska Agricultural Research Division and were released in February 1991.

The low coumarin content of these strains is conditioned by a gene derived from $M$. dentata (W. \& K.) Pers. by means of an initial cross to $M$. alba Desr., made at the Wisconsin Agricultural Experiment Station. The resultant $F_{1}$ seedling was albino, but it was reared to maturity by grafting on a normal green plant (5). A low-coumarin normal green derivative of that hybrid was then crossed to $M$. officinalis by Webster (6) at the Nebraska Agricultural Experiment Station, using embryo culture to overcome the interspecific barrier between $M$. officinalis and $M$. alba. Subsequent to Webster's work, low-coumarin segregates from the latter cross were backcrossed twice to the cultivar, Madrid, followed by one or two backcrosses of low-coumarin segregates to the cultivar, Goldtop.

The development of N28 involved an additional two to four (total of three to six) backcrosses of low-coumarin segregates to Goldtop. Of 199 self-pollinated lines that were composited for planting the initial isolated N28 seed increase block in $1973,33 \%$ had only three backcrosses to Goldtop, $13 \%$ had four backcrosses, and $54 \%$ had six backcrosses. All lines had four cycles of selection (4) for resistance to the sweetclover aphid. In the fourth cycle $81 \%$ of the seedlings survived aphid attack with little or no injury. The sweetclover aphid resistance of N28 was apparently derived from Madrid, or one of the other parents used in transferring the low-coumarin allele to $M$. officinalis since no resistance was observed in Goldtop. However, some of the Goldtop plants used as parents in making the various backcrosses were selected for specific desirable attributes including: (i) resistance to 2,4-dichlorophenoxyacetic acid injury, (ii) resistance to leafhopper [Empoasca fabae (Harris)] injury, or (iii) high nitrate content to increase resistance to the sweetclover weevil (Sitona cylindricollis Fähraeus).

The Syn-1 seed harvested from this initial isolated block in 1974 was held in cold storage until a second isolated N28 seed increase nursery was planted in 1989 . Qualitative tests (3) for $\beta$-glucosidase revealed that all of 348 randomly selected plants from this nursery were high in activity of this enzyme. Because N28 plants had endogenous $\beta$-glucosidase, the addition of this enzyme in the qualitative test for coumarin (3) was unnecessary. The coumarin test thus consisted only of crushing a small amount of leaf tissue on filter paper, drying, adding a drop of $2.5 \mathrm{M} \mathrm{NaOH}$, and immediately examining the moist spots under ultraviolet light of about $360-\mathrm{nm}$ wavelength. Of 412 plants from the N28 nursery that were tested in this way, $15(3.6 \%)$ were classified as high-coumarin. Syn-2 seed was harvested from this nursery in 1990, and a sample of this seed was planted in the greenhouse to allow qualitative testing for coumarin. Of 499 seedlings tested, $39(7.8 \%)$ were classified as highcoumarin.

The development of N29 was similar to that of N28 through the one or two backcrosses of low-coumarin segregates to the cultivar Goldtop. For N29, those backcrosses were fol- lowed by two backcrosses to large-seeded selections from the Turkish introduction, PI 178985. After several generation of self-pollination in which low-coumarin, large-seeded segregates were identified, the selected lines were intermated by open-pollination in isolated field plantings. Two additional selfed generations were screened for resistance to the sweetclover aphid. In the final screening $72 \%$ of the seedlings survived aphid attack with little or no injury. Resistant segregates that were low in coumarin and largeseeded were composited for planting a small isolated nursery in the spring of 1989 . In August 1989 all plants in the nursery were tested qualitatively (3) for $\beta$-glucosidase activity. Of the 605 plants tested, all were found to react positively. In the spring of 1990 all plants in the nursery were subjected to the coumarin test described for $\mathrm{N} 28$, and any plant classified as high-coumarin was removed. The Syn-1 seed harvested from the remaining plants in this nursery in 1990 was designated N29. Seed weight for N29 was $2.6 \mathrm{mg} \mathrm{seed}^{-1}$. This compares with a value of $2.2 \mathrm{mg}$ seed $^{-1}$ for $\mathrm{N} 28$, which is slightly more than values typically observed for Madrid (about $2 \mathrm{mg}$ seed $^{-1}$ ). A sample of $\mathrm{N} 29$ seed was planted in the greenhouse to allow qualitative testing for coumarin. Of 525 seedlings tested, $14(2.7 \%)$ were classified as high-coumarin.

Because the low-coumarin character in sweetclover is determined primarily by a single gene (1), low-coumarin strains such as N28 and N29 can be rapidly contaminated by volunteer seedlings and by outcrossing to high-coumarin plants during seed increase (2). Therefore, future seed increases of $\mathrm{N} 28$ and $\mathrm{N} 29$ should include the testing of plants for coumarin content and the elimination of all high-coumarin plants. For this testing, seedlings must be exposed to several hours of unfiltered sunlight prior to sampling (3). Also, it is highly desirable that each sheet of test spots include, for comparison, a sample of leaf tissue from a plant known to be high in coumarin content that also has been exposed to unfiltered sunlight.

N28 and N29 have not been evaluated in field trials with other sweetclover strains, but both strains carry traits that should be useful in sweetclover improvement programs. Seed of N28 and N29 will be distributed by the Department of Agronomy, University of Nebraska, Lincoln, NE 685830915. Germplasm amounts will be provided without cost to each applicant upon written request while supplies last. Recipients of seed are asked to make appropriate recognition of the source of these germplasms if they are used in the development of new germplasms, parental lines, or cultivars.

\section{H. J. Gorz, * F. A. Haskins, G. R. Manglitz, R. R. SMith, AND K. P. VOGel (7)}

\section{References and Notes}

1. Gorz, H.J., and F.A. Haskins. 1969. Absence of dominance of the $C u$ gene in influencing $o$-hydroxycinnamic acid content in Melilotus alba. Crop Sci. 9:79-81.

2. Gorz, H.J., and F.A. Haskins. 1969. Contamination in Denta sweetclover during successive generations of seed increase. Crop Sci. 9:367369.

3. Haskins, F.A., and H.J. Gorz. 1970. Rapid detection of $o$-hydroxycinnamic acid and beta-glucosidase in Melilotus alba. Crop Sci. 10:479481.

4. Manglitz, G.R., and H.J. Gorz. 1961. Resistance of sweetclover to the sweetclover aphid. J. Econ. Entomol. 54:1156-1160.

5. Smith, W.K. 1943. Propagation of chlorophyll-deficient sweetclover hybrids as grafts. J. Hered. 34:135-140.

6. Webster, G.T. 1955. Interspecific hybridization of Melilotus alba $\times$ M. officinalis using embryo culture. Agron. J. 47:138-142. 
7. H.J. Gorz (retired) and K.P. Vogel, USDA-ARS and Dep. of Agronomy, and F.A. Haskins (retired), Dep. of Agronomy, G.R. Manglitz (retired), USDA-ARS and Dep. of Entomology, Univ. of Nebraska, Lincoln, NE 68583-0915; and R.R. Smith, USDA-ARS, U.S. Dairy Forage Res. Ctr., and Dep. of Agronomy, Univ. of Wisconsin, Madison, WI 53706. Cooperative investigations of the USDA-ARS and the Nebraska Agric. Res. Div. Published as Journal Series Paper no. 9569, Nebraska Agric. Res. Div. Registration by CSSA. Accepted 30 Sept. 1991. *Corresponding author.

Published in Crop Sci. 32:510 (1992). 